DOI: $10.12731 / 2227-930 X-2020-3-7-17$

UDC 621.3.049.76 (063); 681.3.01 (063)

\title{
TEMPERATURE FIELD OF EXHAUST CARS GASES AND CALCULATIONS OF THE STATISTICAL INFORMATION
}

Nasr T., Voinov K.N., Hildayati A., Al-Raidi A.

There are too many problems from the gases which constantly fly out from the exhaust pipes of cars and lorries, especially if this process takes place in the closed apartment (garage, laboratory, class, station of diagnostic or repair for transport systems with diesel or petrol engine). Practically all gases poison air, bring essentially injury to the health of people and for the all nature. Hitherto, many scientists affirm that gases create the negative hotbed effect in the atmosphere and influence to the appearance of the ozone holes. Some important experiments and investigations at the present day didn't make.

In this article there are several technical decisions not only how to decrease the negative influence of gases but the special calculations using personal computer and statistical information to describe the process by a chart.

Keywords: exhaust gases; protection; temperature; pollution; calculation; statistical information.

\section{ТЕМПЕРАТУРНОЕ ПОЛЕ ВЫХЛОПНЫХ ГАЗОВ АВТОМОБИЛЕЙ И РАСЧЁТЫ СТАТИСТИЧЕСКИХ СВЕДЕНИЙ}

\author{
Наср Т., Войнов К.Н., Хилдаяти А., Аль Райди А.
}

Существует много проблем с газами, которые вылетают постоянно из выхлопных труб легковых автомобилей и грузовиков, особенно если имеет место этот процесс в закрытых помещениях (гараж, лаборатория, класс, станция диагностики или ремонта транспорт- 
нылх систем с дизельным или бензиновым двигателем). Практически все газы отравляют воздух, приносят существенный вред здоровью людей и всей природе. Поэтому многие учёные утверждают, что газы создают негативный парниковый эффект в атмосфере и влияют на появление озоновых дыр. Некоторые важные эксперименты и исследования в настоящее время сделаны.

$B$ этой статье есть несколько технических решений не только как уменьшить негативное влияние газов, но и специальные расчёmы, используя персональный компьютер и статистическую информацию, чтобы описать прочесс графически.

Ключевые слова: выхлопные газы; зашита; температура; загрязнение; расчёть; статистическая информация.

\section{Introduction}

It is common knowledge, that any exhaust gases from the cars/lorries have the very bad and even dangerous influence to the man health. Namely, at the present day any type of cancer (as the illness) is the most dangerous for people. Unfortunately, these harmful gases take practically the first or maybe the second place as gases from the works, factories and boiler-houses which make the same negative effect. Moreover, hot gases constantly increase the temperature around the Earth. That's why any even a small achievement which can diminish this harmful influence from these gases on the surrounding environment it plays the very important significance. In this paper one new and effective technical decision to defend our atmosphere against these dangerous exhaust gases is presented.

Text 1. It has suggested how to quickly delete the harmful exhaust gases which are fling constantly into the air from the cars and lorries. It is needed to direct these gases into the water reservoir. In this case the most injurious chemical elements and their combinations will be on the bottom of the water pool or they'll float in it [1-3]. Of course, periodically the water reservoir must be cleaned. At the same time the hot temperature from these gases will be diminished essentially (practically to the normal level). 
The first step of our control was linked with the test of temperature which is changing behind the end of the exhaust pipe depending on many factors, namely: type engine, it's term of operation, fuel, regime of combustion (start, normal or forced regime), temperature around the place of measurement, velocity of wind, the distance from the end of exhaust pipe till the point where the temperature was fixed by thermometer.

In a capacity of auxiliary instruments were taken the next: ruler (length about $500 \mathrm{~mm}$ ) and thermometer which can show not less than $200 \mathrm{oC}$. All fixed results were written down on the leaflet. Moreover, the measurements were written down on the middle line with the hole of the exhaust pipe, then 50 and $100 \mathrm{~mm}$ above and below of the end of the pipe and on the length till $300 \mathrm{~mm}$. Well, the same measurements of temperature were made from the both sides of the exhaust pipe. This information connected with these points of the temperature control during our investigation is given in Fig. 1.
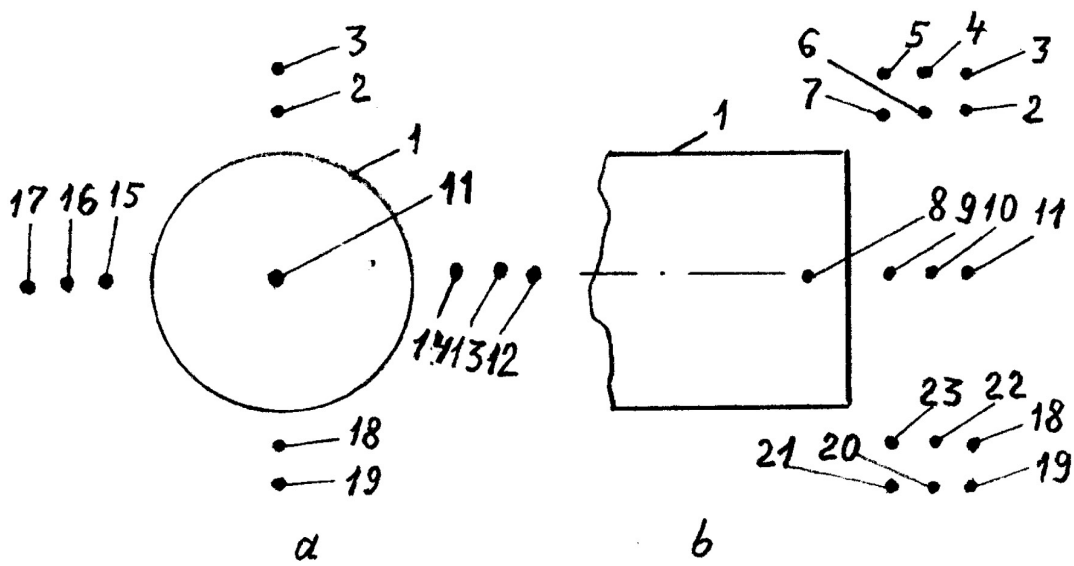

Fig. 1. Points where the end of thermometer was installed: $a$-is the view from the face; $b$ - from one side (lengthways)

In most cases the distances between places where the temperature is measured was $50 \mathrm{~mm}$, for example: number $2-3 ; 18-19 ; 12-13$; 13-14; $15-16 ; 16-17 ; 5-7 ; 4-6 ; 3-2 ; 23-21 ; 22-20 ; 18-19$, but the lengthwise of 
the pipe these distances were $100 \mathrm{~mm}$ between points 6-7; 2-6; 22-23; $22-18 ; 20-21$ and 19-20. And the same distance in $100 \mathrm{~mm}$ was between the next points $8-9 ; 9-10$ and $10-11$.

Position number 1 is designated for the exhaust pipe. Position 8 is the point inside the pipe (the distance from the end of the pipe was about $15 \mathrm{~mm}$ ).

The measured temperatures (oC, bold type) in these points were:

$52,43,21,2$ (points $8,9,10,11$ for the line which is going through the centre of pipe); $14,8,3$ (points $7,6,2$ ); 5, 3, 1 (points 5, 4, 3); 3, 2, 1 (points 21, 20, 19);

$6,3,1$ (points $23,22,18$ ); 22, 11, 1 (points $14,13,12$ ); 11, 5, 1 (points 15, 16, 17).

The common field of temperatures is shown in Fig. 2. The investigation process was made 09.11.2019 quite near to the ITMO University (Saint-Petersburg) when the external air temperature was about + $1 \mathrm{oC}$ only. The wind in the day of testing was not more than 1 metre per second. Using written computer programme MathCad let's get the equations which describe the distribution of temperature in all cases (Fig. 2 and Fig. 3) and at the same time to represent the appropriate curves $[4,5]$.

$$
\begin{aligned}
& i:=1 . .4 ; \quad h:=50 ; \quad L_{0}=\frac{L_{1}+L_{n}}{2}=75 ; \quad L_{n}:=150 ; \quad H_{2}:=n \cdot\left(n^{2}-1\right) \cdot \frac{n^{2}-4}{180}=4 \quad L_{1}:=0 ; \\
& H_{1}:=n \cdot \frac{n^{2}-1}{12}=5 \quad d_{0}:=\sum_{i} \frac{d_{i}}{n}=29.5 \\
& a:=\frac{1}{12 \cdot H_{2}} \cdot\left[3 \cdot\left[\sum_{i}\left[d_{i} \cdot(2 \cdot i-n-1)^{2}\right]\right]-\left(n^{2}-1\right) \cdot\left(\sum_{i}^{n} d_{i}\right)\right]=-2.5 \\
& b:=\frac{1}{2 \cdot H_{1}} \cdot\left[{ }_{i}\left[d_{i} \cdot(2 \cdot i-n-1)\right]\right]=-17.2 \quad c:=d_{0}-\frac{H_{1} \cdot a}{n}=32.625 \\
& W_{i}:=a \cdot \frac{\left(L_{i}-L_{0}\right)^{2}}{h^{2}}+b \cdot \frac{L_{i}-L_{0}}{h}+c
\end{aligned}
$$


Table 1.

\begin{tabular}{|c|c|c|}
\hline$d_{i}$ & $L_{i}$ & $W_{i}$ \\
\hline 52 & 0 & 52 \\
\hline 43 & 50 & 40.6 \\
\hline 21 & 100 & 23.4 \\
\hline 2 & 150 & 1.2 \\
\hline
\end{tabular}

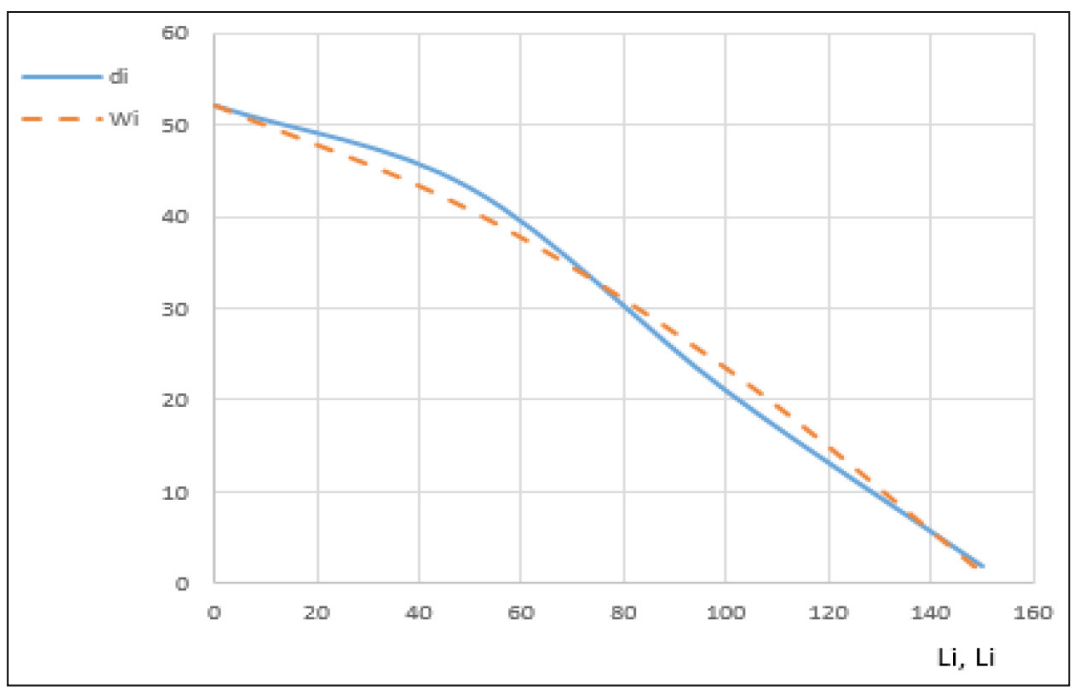

Fig. 2. Experimental and theoretical data connected with the temperature alteration along the center line of the pipe (from within to the outside)

The non-linear coincidence for this parabola approximation is very well. Above we took into account the even points of observation $(n=4)$, but further there are information of temperature with $n=3$ (odd amount of points for control). $t 1_{i}$

\begin{tabular}{|c|c|c|c|c|c|c|}
\hline$t 1_{i}$ & $t 2_{i}$ & $t 3_{i}$ & $t 4_{i}$ & $t 5_{i}$ & $t 6_{i}$ & $L_{i}$ \\
\hline 14 & 5 & 3 & 6 & 22 & 11 & 100 \\
\hline 8 & 3 & 2 & 3 & 11 & 5 & 200 \\
\hline 3 & 1 & 1 & 1 & 1 & 1 & 300 \\
\hline
\end{tabular}

Table 2. 


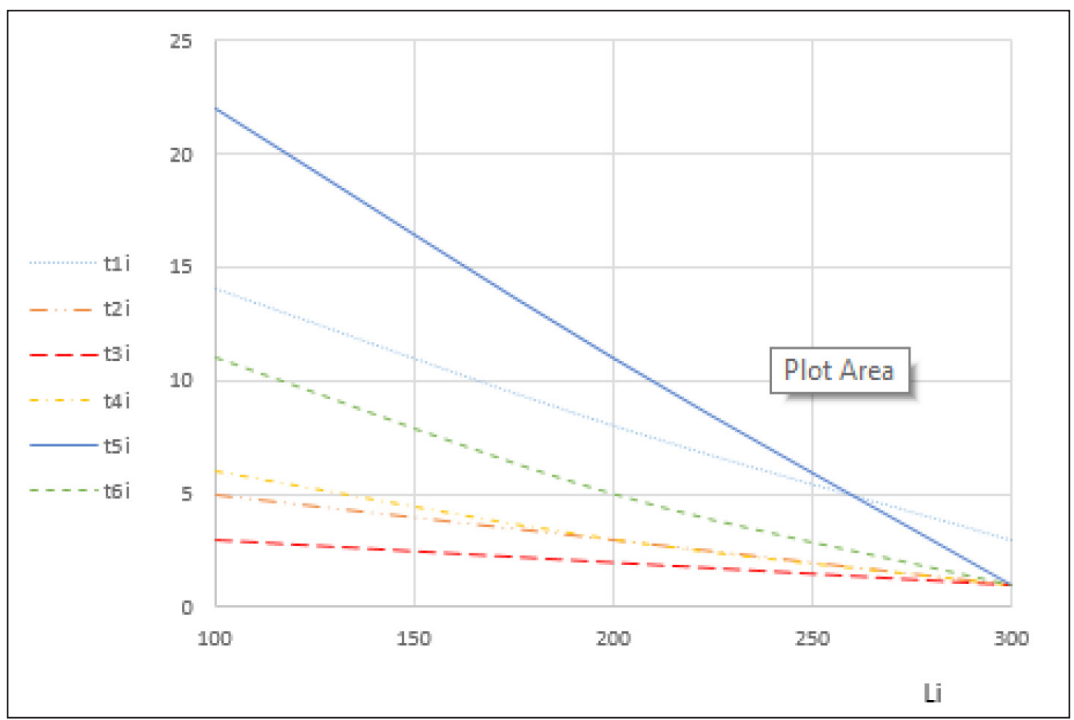

Fig. 3. Six lines which show how the temperature changes in different points of measurements dimensions and in accordance with their positions

Therefore, the water in reservoir will not become hot extremely and as an addition result the evaporations will not be too strong from the water surface. This programme of calculation and common analysis were made many times.

Text 2. Experimental investigation consisted of taking away gases from different motor vehicles which are working using petrol or diesel fuel $[6,7]$. For this aim special technical pears (like an enema), measuring-glasses, thermometer and distillation water were bought.

Moreover, special devices Tensor-37 FT-IR (firm BRUKER OPTIK $\mathrm{GmbH}$ with standard detector DLaTGS) and spectrum-scan Max-GV were applied as well.

They help to make the chemical analyses of the originally clean water with exhaust gases. For this purpose, the first measurement was obtained using this device (Fig. 4) and with computer programme, chart and calculations (Fig. 5). 


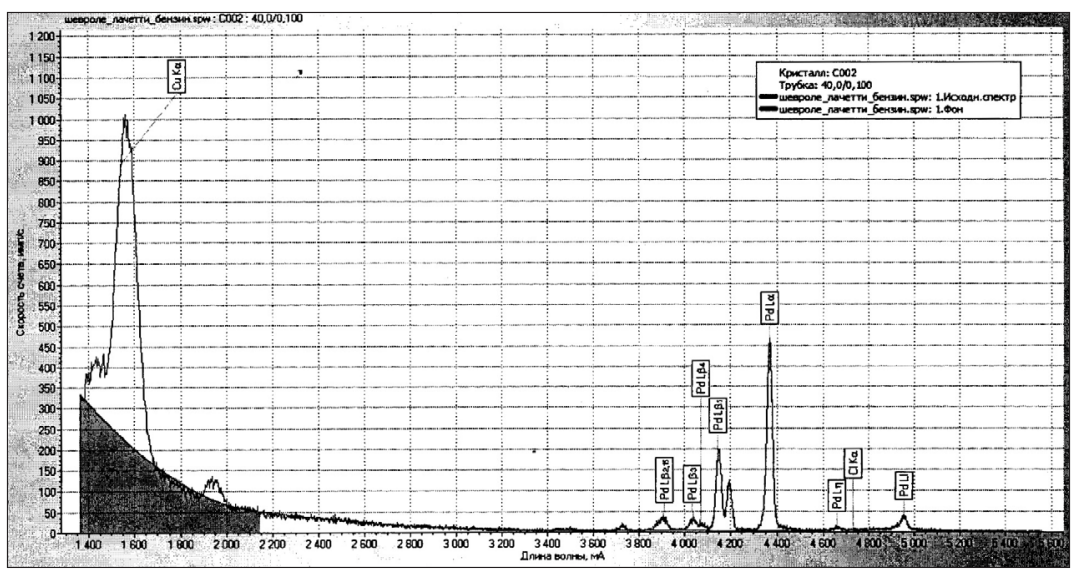

Fig. 4. The first information obtained from the motor vehicle (Chevrolet) /velocity of calculation as a function of the length for wave/

After the full gathering of statistical information about exhaust gases from different motor vehicles we plan to get important picture of influence gases and their harmful characteristics on our medium.

Approximate description of this figure 4 with the computer programme MathCad is given below. It's no difficult to get the mathematical equation too.

Table 3 .

\begin{tabular}{|c|c|}
\hline$V_{i}$ & $L_{i}$ \\
\hline 325 & 1420 \\
\hline 940 & 1570 \\
\hline 260 & 1720 \\
\hline 140 & 1870 \\
\hline 68 & 2060 \\
\hline 54 & 2170 \\
\hline 48 & 2320 \\
\hline 40 & 2470 \\
\hline 26 & 2622 \\
\hline 24 & 2770 \\
\hline 20 & 2920 \\
\hline 16 & 3070 \\
\hline 9 & 3220 \\
\hline
\end{tabular}




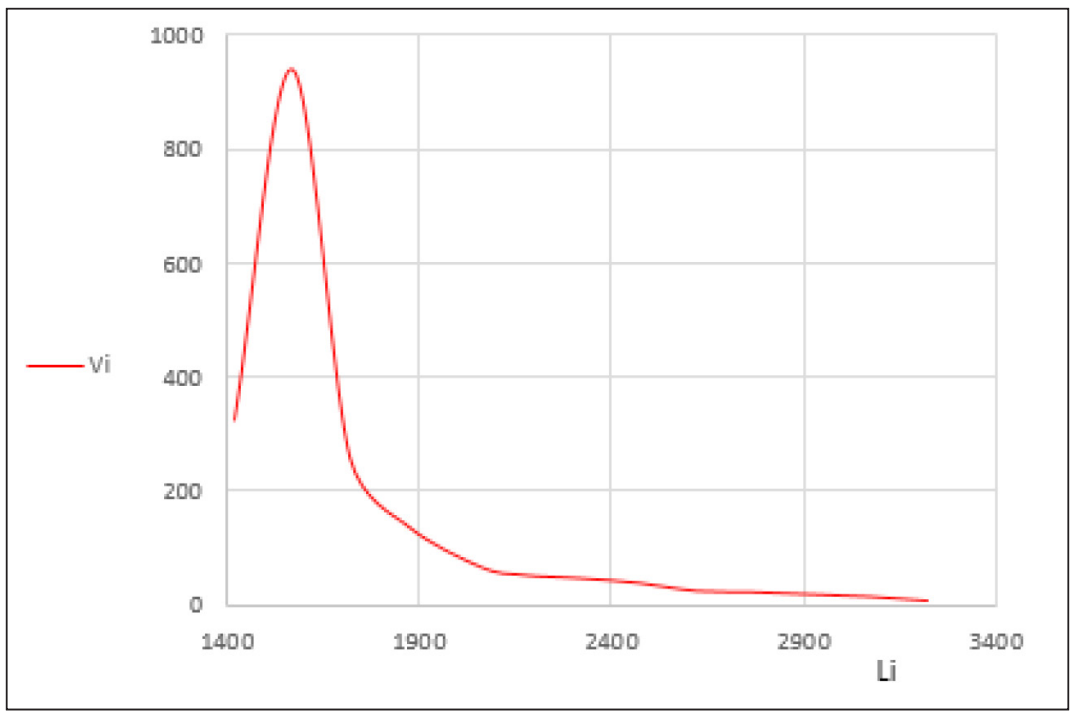

Fig. 5. Chart to approximate the description for the initial part of statistical data

\section{Results and Conclusion}

Thus, the description how people can essentially decrease the harmful influence of the motor vehicles gases on the media is given here. The temperature changes were investigated for the first time around the exhaust pipes. These experiments show that the temperature in the water (where gases will go) aren't too hot and any essential evaporation will be absent. This very simple method to neutralize the high hot temperature from the exhaust gases helps to defend the environment (ozone holes and hotbed effect cannot appear at all) and water in reservoir annihilates many carcinogenic chemical components/elements which take always place in the exhaust gases.

\section{Discussions}

Expanded new way to diminish negative influence from the automobile exhaust gases which is represented in detail in here is the simplest and the cheapest at the present day among the many others well-known ways in this plan. Moreover, it can be realized very easy in practice. 


\section{References}

1. Tribologiya: mezhdunarodnaya entsiklopediya. Tom XI. Komp'yuternye programmy i primery raschetov $v$ tribologii i tribotekhnike [Tribology: an international encyclopedia. Volume XI. Computer programs and examples of calculations in tribology and tribotechnics]. / Ed. Doctor of Technical Sciences, Professor, Academician Voinov K.N., St. Petersburg, ITMO University, "Nestor-Istoriya", 2016. 240 p.

2. Tribologiya: mezhdunarodnaya entsiklopediya. Tom X. Modelirovanie $i$ raschety $v$ tribologii $i$ nadezhnosti [Tribology: an international encyclopedia. Volume X. Modeling and Calculations in Tribology and Reliability]. / Ed. Doctor of Technical Sciences, Professor, Academician Voinova K.N., St. Petersburg, ITMO University, "Nestor-Istoriya", 2015, 200 p.

3. Voynov K.N. Problemy i resheniya v voprosakh treniya/iznashivaniya [Problems and Solutions in Friction / Wear Issues]: monograph. SPb.: Nestor-History, $2015.500 \mathrm{p}$.

4. Dyakonov V.P. Mathcad 8/2000: Spetsial'nyy spravochnik [Mathcad 8/2000: A Special Reference]. SPb.: PETER, 2001. 592 p.

5. Kiryanov D.V. Samouchitel' Mathcad 2001 [Self-instruction manual Mathcad 2001]. SPb .: BHV-Petersburg, 2001. 544 p.

6. Voynov K.N., Gkhellab Ya. O zagryaznenii vozdukha avtomobil'nymi gazami [On air pollution by automobile gases]. Tribologiya: Mezhdunarodnaya entsiklopediya [Tribology: International encyclopedia]. 2017. Vol. XII. P. 127-129.

7. Voynov K.N., Vasil'ev V.A., Khildayati A., Gkhellab Ya. Novyy podkhod k umen'sheniyu zagryazneniya vozdushnogo prostranstva [A new approach to reducing air pollution]. Tribologiya: Mezhdunarodnaya entsiklopediya [Tribology: International encyclopedia]. 2017. Vol. XII. P. 130-133.

\section{Список литературы}

1. Трибология: международная энциклопедия. Том XI. Компьютерные программы и примеры расчётов в трибологии и триботехнике. /Под ред. д.т.н., профессора, академика Войнова К.Н., Санкт-Петербург, Университет ИТМО, «Нестор-История», 2016. 240 с. 
2. Трибология: международная энциклопедия. Том Х. Моделирование и расчёты в трибологии и надёжности. /Под ред. д.т.н., профессора, академика Войнова К.Н., Санкт-Петербург, Университет ИТМО, «Нестор-История», 2015. 200 с.

3. Войнов К.Н. Проблемы и решения в вопросах трения/изнашивания: моногр./ К.Н. Войнов. СПб.: Нестор-История, 2015. 500 с.

4. Дьяконов В.П. Mathcad 8/2000: Специальный справочник. СПб.: ПИТЕР, 2001. 592 с.

5. Кирьянов Д.В. Самоучитель Mathcad 2001. СПб.: БХВ-Петербург, 2001. 544 c.

6. Войнов К.Н., Гхеллаб Я. О загрязнении воздуха автомобильными газами // Трибология: Международная энциклопедия. 2017. Т. XII. С. 127-129.

7. Войнов К.Н., Васильев В.А., Хилдаяти А., Гхеллаб Я. Новый подход к уменьшению загрязнения воздушного пространства // Трибология: Международная энциклопедия. 2017. Т. XII. С. 130-133.

\section{DATA ABOUT THE AUTHORS}

Nasr Tareq Mohammed Abduljabbar, post-graduate student

University ITMO

49A, Kronverkskiy pr., St. Petersburg, 197101, Russian Federation

tarek01021988@mail.ru

Voinov Кирилл Николаевич, Dr. of Tech. Sci., Professor

University ITMO

49A, Kronverkskiy pr., St. Petersburg, 197101, Russian Federation

forstar@mail.ru

Hildayati Annisa, post-graduate student

University ITMO

49A, Kronverkskiy pr., St. Petersburg, 197101, Russian Federation annisa.hildayati@mail.ru 
Al-Raidi Aiman Humadi Mohammed Hussein, master student University ITMO 49A, Kronverkskiy pr., St. Petersburg, 197101, Russian Federation aymanalraidy2017@mail.ru

\section{ДАННЫЕ ОБ АВТОРАХ}

Наср Тарек Мохаммед Абдулджаббар, аспирант

Национальный исследовательский университет ИТМО пр. Кронверкский, 49А, г. Санкт-Петербург, 197101, Российская Федераџия tarek01021988@mail.ru

Войнов Кирилл Николаевич, доктор технических наук, профессор, Наииональный исследовательский университет ИТМО пр. Кронверкский, 49А, г. Санкт-Петербург, 197101, Российская Федерачия forstar@mail.ru

Хилдаяти Анниса, аспирант

Национальный исследовательский университет ИТМО пр. Кронверкский, 49А, г. Санкт-Петербург, 197101, Российская Федерачия annisa.hildayati@mail.ru

\section{Аль Райди Аиман Хумади Мохаммед Хуссейн, магистрант}

Национальный исследовательский университет ИТМО пр. Кронверкский, 49А, г. Санкт-Петербург, 197101, Российская Федераџия

aymanalraidy2017@mail.ru 